\title{
MEDICAL-LEGAL PROBLEMS OF INTERFERENCE IN THE RIGHT TO HUMAN AUTONOMY IN POSTMORTEM REPRODUCTION
}

DOI: 10.36740/WLek202012231

\author{
Olga Ye. Avramova, Oleksandr Ye. Kukhariev \\ KHARKIV NATIONAL UNIVERSITY OF INTERNAL AFFAIRS, KHARKIV, UKRAINE
}

\begin{abstract}
The aim is a theoretical and methodological substantiation of revealing the possibility of interfering in the autonomy of a person during posthumous reproduction and establishing the existing protection of the rights and interests of postmortem children.

Materials and methods: The legislation of the European Union, the USA, Great Britain, New Zealand, Spain, Germany, Ukraine, the statistical data published by the international organizations are analyzed. In the course of the research a systemic, axiological approach and methods of analysis, synthesis, generalization were used.

Conclusions: It is proved that reproductive interference in the autonomy of the deceased in order to have a child is possible only on law basis, and in its absence - by a joint decision of the council of doctors, family lawyers, relatives of the deceased, taking into account the moral principles of society, public interests, rights and interests and other constituents (other heirs). It is emphasized that the origin of a postmortem child can be established based on a court decision. It is emphasized that post-mortem children should not have any discrimination; they are equal with other children. It was found that the system of rights of postmortem children includes personal non-property rights of a child (right to life, health, name, surname of biological parents); property rights (right to inheritance, right to social security). The primary is the system of non-property rights that ensure the physical and social life of the postmortem child.
\end{abstract}

KEY WORDS: autonomy, interference, life, postmortem children, reproduction

Wiad Lek. 2020;73(12 p. II):2890-2894

\section{INTRODUCTION}

Due to modern medical technology, posthumous reproduction becomes available to anyone. This possibility was first announced in the late 1970s by Cappie Rothman - urologist from the Los Angeles, according to which Gabi Vernoff gave birth to a baby girl, Brendalin, through sperm obtained by Rothman 30 hours after her husband died. According to the US Sperm Bank, only three such procedures were performed in the 1980s, and fifteen in the 1990s, and from 2000 till 2014, its number increased to 130 averaging eight each year. Despite the obvious medical progress in posthumous reproduction, several medical and legal problems still arise in this area. In particular, it is the legitimacy of interfering in the right to human autonomy after death, possibility of protecting the rights of a postmortem child (from the Latin post mortem - posthumous). In modern European legislation, the issue of reproduction of human tissues is regulated by Commission Directives 2004/23/EU, 2006/17/EU (8, February 2006), 2012/39/EU (26, November 2012) of the European Parliament and of the Council on certain technical requirements for donation, obtaining and testing of human tissues and cells [2]. Despite the regulation of technical issues of reproduction, posthumous reproduction before doctors, lawyers, relatives of the deceased there are some complex problems about the feasibility of its implementation, possibility of interfering in posthumous human autonomy, prospects for a healthy child, full protection of their rights.

\section{THE AIM}

The aim of the paper is theoretical and methodological substantiation of identifying the possibility of interfering in the autonomy of a person during posthumous reproduction and establishing the existing protection of the rights and interests of postmortem children.

\section{MATERIALS AND METHODS}

This study was conducted during June-August 2020. The main materials of the study are the provisions of Commission Directives 2004/23/EU, 2006/17/EU (8, February 2006), 2012/39/EU (26, November 2012) of the European Parliament and of the Council, legislation of the European Union, the United States, the United Kingdom, New Zealand, Spain, Germany, Ukraine on reproductive technologies and statistics published by international organizations. The basic research methods are analysis, synthesis, formal-legal method. Exactly these methods have made it possible to establish the actual and legal capacity for post-mortem reproduction and related legal issues regarding the protection of the rights of a postmortem child. A systematic approach was used to identify a set of medical and legal issues in the field of posthumous reproduction: the possibility of interfering in a person's autonomy after his/her death and protecting the rights of a newborn child after the death of one parent. The ap- 
plication of the axiological method revealed the values of posthumous reproduction.

\section{REVIEW AND DISCUSSION}

I.V. Venediktova drew attention to the urgency of protection of the rights and interests of postmortem children in the study of reproductive relations [3]. The need to establish a balance of interests of the postmortem child, one of the parents, other heirs is determined in the work of M.L. Shelyutto [4]. The work of S. Simanna is devoted to the question of whether posthumous reproduction should be allowed in the absence of the prior consent of the deceased [5]. E. Harbinya addresses the issue of human rights after death [6]. Finally, the ethical component of postmortem birth was the subject of J. Greenfield's research [7].

Analyzing various scientific sources, it should be noted that in science and practice there is no common understanding of ethical and legal issues in the field of interference in the autonomy of the deceased, as well as the rights and interests of postmortem children. The problem of this issue is sometimes exacerbated by opposing approaches in the legal regulation of these relations, which is established by different states, which is reflected in diametrically opposed scientific positions. Therefore, the topic of protection of interference in the autonomy of a person during the posthumous reproduction, as well as ensuring the rights and interests of postmortem children is relevant for research.

The appearance of a postmortem child is the result of medical intervention in a person's autonomy, his/her physical genetic integrity and lifelong intentions. Such interference in scientific sources has not received a single conceptual position, as it is a complex ethical and legal issue. It also needs medical research and observation, including post-mortem reproduction, post-mortem fertilization, family and community development. In medical practice, there is still insufficient data on the psycho-emotional, physiological state of such children. Therefore, the legal regulation of the relevant relations is still in the process of formation. However, it should not be premature than medical conclusions about the safety of such a child.

At the same time, legal scholars insist that in order to ensure the realization of the rights and interests of the testator's postmortem children, in particular, in the field of inheritance, such persons should be legally defined as heirs. It is fundamental that every child, regardless of procedure of origin, should have equal rights with other children, because a born postmortem child can not have an idea of their origin and intentionally influence their appearance.

Legal regulation of posthumous reproduction and the status of a postmortem child, as noted above, are established differently in foreign legal systems. For example, New Zealand has developed Guidelines for the use of surviving ovum after the death of a woman, using of surviving embryos after the death of one or both gamete donors, collection of sperm from a deceased man, removal and using of dead woman's ovum, removal and use of reproductive tissues of a deceased man or woman [8].
Judicial practice regarding the rights and interests of postmortem children has developed in the United States, however, not always in positions of protection of the rights and interests of such children. For example, the decision of the Supreme Court of the United States in the case "Astrue v. Capato ex rel. B.N.C., 566 US 541 (2012)" regarding the rights of twins conceived as a result of in vitro fertilization 18 months after the death of their father, the right to social security was denied. The court relied on section 416 (h) (2) (A) of the Social Security Act, holding that twins may receive social security benefits "only if they are entitled to inherit from the deceased under state will law" Astrue, 566 USA, 559. Because the deceased was living in Florida at the time of death, Florida's will law applied, and children were not entitled to an inheritance, depriving them of the right to social security benefits. The Massachusetts Supreme Court has ruled that there are limited circumstances in which posthumously conceived children may exercise the right to inherit under a will, including: (1) they have a surviving father or legal representative who must prove genetic relatedness; (2) the deceased father gave his unambiguous consent to the posthumous reproduction; (3) the submission of an application for acceptance of the inheritance corresponds to the statute of limitations [9].

It follows from the above that the protection of the rights of postmortem children still remains uncertain. This is partly due to the fact that the birth of a child after the death of one of the parents is interference in certain autonomy of a person after his/her death. Autonomy of human rights is based on the fourth generation of human rights, which provides independence and alternativeness of the person in the choice of lawful behavior within the norms of morality and law [10, p. 106]. Accordingly, a person should have the right to choose the possibility of genetically inheriting their lineage and no one can interfere with this right. Autonomy should, in principle, transcend death, allowing people to control their confidentiality / identity / personal data after death, similar to their posthumous control over property through the concept of freedom of will [7]. Along with this, scientific sources put forward two different concepts of respect for autonomy: 1) the model of "non-interference", according to which it is inadmissible to interfere in the human body without his/her prior consent; 2) the model of "respect for desire", according to which we should treat a person as he/she most likely would like to be treated [6].

A two-pronged approach to this complex ethical and legal issue needs to be addressed at the regulatory level. In the case of proper legal regulation, the problem of interfering in the autonomy of a person after his/her death is transferred to the state, which must develop mechanisms for permissible and inadmissible, such interference. For example, a written refusal to donate reproductive material for the life of a deceased person may be considered as a person's reluctance to continue genetically. At the same time, public interests and the interests of other persons must be considered [4, p. 49]. Thus, interference in the autonomy of the deceased is possible only on the law basis, and in its absence - by a joint decision of the council of doctors, 
family lawyers, relatives of the deceased, considering the moral principles of society, public interests, rights and interests of relatives and other constituents, heirs). It is always a coercive interference with the integrity of the deceased and is therefore a coercive act. An exception to this rule is when a person freezes their gametes for artificial insemination with the gametes of a particular person, i.e. enters into a contract, as evidenced by civil contracts or other documents (applications, approvals, treatment programs in the health care facility, etc.) [11, p. 36].

The medical possibility of postpartum children raises several important legal issues: the establishment of identity between the deceased and the child born, legal establishment of the child's origin and legal status. Establishing the origin of the child from the deceased has two aspects: physiological (direct use of biomaterials of the deceased for the birth of a child); legal (interference in human autonomy regarding the desire to have children). Physiological origin should be traceable. This sign is established by item g, Art. 1 of Commission Directive 2006/17 / EU (8, February 2006): "traceability" means the ability to locate and identify a tissue / cell at any stage from procurement, processing, testing and storage to disposal to a recipient or disposal; traceability also includes the ability to identify a donor, tissue establishment, or manufacturing facility that receives, processes, or stores tissues / cells, and ability to identify recipients in medical facilities where tissues/ cells are applied to recipients; traceability also includes the ability to locate and identify all relevant data relating to products and materials in contact with such tissues/cells" [12]. Therefore, when conducting genetic identification of a postmortem child, it is necessary to identify a sign of traceability between the cells of the child and the donor.

Let's pay attention to the fact that in vivo cryopreservation of genetic material (gametes, embryos) in itself does not necessarily indicate a person's intention to resort to posthumous reproduction: in some cases, delivery of genetic material and the creation of embryos is planned only their lifetime use in purposes of childbirth, in others - both variants of reproduction are used (lifelong, posthumous) or the task of posthumous conception is directly set taking into account the expected or probable death of a person seeking to have a child $[5$, p. 92]. Due to the existence of different behaviors of a person in donation, the question of establishing the origin of the child is open, which is to some extent due to the state of regulation of relevant legal relations in the laws of foreign countries.

For example, on 18 September 2003, the British Parliament passed amendments to the law requiring any man wishing to be the father of a child born as a result of using of reproductive technology after his death to give his prior written consent to such record [13, p. 34]. In some countries to determine the origin of the child it is necessary to conduct a paternity test and posthumous consent to conception [6, p. 285]. Similarly, Article 9.2 of the Spanish Law on Assisted Reproductive Methods of 26 May 2006 allows the use of reproductive material for twelve months after the death of a husband to inseminate his wife with legal consequences arising from family origin. The use of reproductive material after death is possible subject to the husband's consent in a special document, will or instruction. This right is also granted to unmarried men. To regulate the legal status of future embryos, they are considered as nastiturus [14].

According to Articles 128 and 132 of the Family Code of Ukraine, the basis for recognition of paternity is any information certifying the origin of the child from a certain person; in the event of the death of a woman who considered herself the mother of the child, the fact of her motherhood may be established by a court decision [15]. Thus, in Ukraine, the origin of a postmortem child can be established on the basis of a court decision.

In addition to the origin of the postmortem child, the question of the legal status of such a person is acute. In our opinion, in this aspect the fairest is the application of the preamble of the Universal Declaration of Human Rights on Equality of Human Rights [16]. That is, postmortem children should not be discriminated against in any way; they are equal to other children in all legal relationships, including hereditary ones.

Moreover, it is in the field of inheritance that the problem of determining the legal status of postmortem children remains unresolved. Under Ukrainian law, such a person is deprived of the legal opportunity to be called upon to inherit both by law and by will. Although the legal doctrine has formed two opposing positions on the possibility of recognizing inheritance rights for a child, not only born but also conceived after the discovery of the inheritance. Proponents of the former generally deny inheritance by postmortem children, arguing that legal uncertainty that exists between the day of the opening of the inheritance and the possible birth of a child, which, in turn, can lead to the destruction of the structure of all inheritance law [17].

Other scholars, on the other hand, believe that the testator's child belongs to the first priority heirs, regardless of the method of conception and delivery, as well as regardless of the birth date after the testator's death, if the testator left genetic material for subsequent birth of a child [18, p. 260].

The issue of recognition as an heir of a person born as a result of posthumous reproduction is regulated differently in foreign legislation. Yes, in some countries the inheritance rights of such children are denied. Other states refer to the circle of heirs of the testator's postmortem children. In particular, according to $\$ 2101$ of the German Civil Code, in the case of the appointment of the person's heir not conceived at the time of commencement of succession, it should be considered an additional heir, unless proven otherwise. If the will of the testator does not meet the need for additional heirs, then such an appointment is invalid. Prior to the birth of a child conceived after the death of the testator, the main heirs are the legal heirs ( $\$ 2105$ of the German Civil Code) [19].

It should be noted that the inheritance of post-mortem children must ensure both the stability of property turnover and the interests of other participants in the relevant legal relations - heirs, recipients, creditors of the testator. That 
is why the recognition of postmortem children as heirs should be carried out subject to certain conditions. This is primarily a period during which artificial insemination can be performed using assisted reproductive technologies. In our opinion, such a period should be six months from the date of commencement of succession, as it corresponds to the period established for its acceptance. Also, the condition of inheritance by postmortem children is proposed to recognize the relevant order of the testator expressed in the will. That is, recognition of such persons as heirs, taking into account their conception after the commencement of succession, should be carried out only at the will of the testator. Otherwise, the proposed proposal may be a fertile ground for numerous abuses by other parties to the relationship. Thus, it seems more appropriate to limit inheritance by postmortem children to inheritance by will, without changing the range of heirs at law, which are imperatively defined by law.

We believe that the general system of rights of postmortem children should be regulated. This system should be built taking into account the principle of equality of rights with other subjects of legal relations. Such a system should include: 1) personal intangible rights of the child (right to life, health, name, and surname of biological parents); 2) property rights (right to inheritance, right to social security). At the same time, primary system is the non-property rights that ensure physical and social life of the postmortem child.

\section{CONCLUSIONS}

1. Reproductive interference in the autonomy of the deceased in order to have a child is possible only on the basis of law, and in its absence - by a joint decision of the council of doctors, family lawyers, deceased's relatives, taking into account the moral principles of society, public interests, rights and interests of relatives and other interested persons (other heirs).

2. In case of disputes, the origin of the postmortem child may be established on the court decision basis. These children should not have any discrimination; they are equal to other children.

3. Post-mortem children shall not be discriminated against in any way or on an equal footing with other children on the basis of origin or other characteristics.

4. The system of rights of postmortem children includes: 1) personal intangible rights of the child (right to life, health, name, and surname of biological parents); 2) property rights (right to inheritance, right to social security). The primary is the system of non-property rights that ensure physical and social life of the postmortem child.

5. Promising direction of research is to identify and address problems that arise due to inadequate protection of the rights and interests of postmortem children.

\section{REFERENCES}

1. Morber D, Khochu dytynu lyshe vid noho. Chy etychno vykorystovuvaty spermu pomerloho. Available from: https://www.bbc.com/ukrainian/ vert-fut-44794575 [reviewed 2020.08.20] (Ua).
2. Commission Directive 2012/39/EU of 26 November 2012 amending Directive 2006/17/EC as regards certain technical requirements for the testing of human tissues and cells Text with EEA relevance. $0 \mathrm{~J} \mathrm{~L} 327$, 27.11.2012, p. 24-25 (BG, ES, CS, DA, DE, ET, EL, EN, FR, IT, LV, LT, HU, MT, NL, PL, PT, RO, SK, SL, Fl, SV). Special edition in Croatian: Chapter 15 Volume 027 P. 53 - 54. Available from: https://eur-lex.europa.eu/ legal-content/EN/TXT/?uri=celex:32012L0039 [reviewed 2020.08.20].

3. Venediktova I, Realization and protection of interests of persons in reproductive legal relations. [Realizatsiia i zakhyst interesiv osib u reproduktyvnykh pravovidnosynakh]. Yurydychna Ukraina. 2012; 11:46-50. (Ua).

4. Sheliutto M, Dety, zachatie posle smerty rodytelia: ustanovlenye proyskhozhdenyia y nasledstvennыe prava. Zhurnal zarubezhnoho zakonodatelstva y sravnytelnoho pravovedenyia. 2016; 4:91-98. (Ru).

5. Simana S, Creation of life after death: should posthumous reproduction be allowed without the prior consent of the deceased? Journal of Law and Biological Sciences. 2018; 5.2:329-354. doi: 10.1093 / jlb / lsy017.

6. Harbinja E, Post-mortem privacy 2.0: theory, law, and technology, International Review of Law, Computers \& Technology. 2017; 31:1: 26-42, doi: 10.1080/13600869.2017.1275116.

7. Greenfield J, Dad Was Born A Thousand Years Ago? An Examination of PostMortem Conception and Inheritance with a Focus on the Rule against Perpetuities. Minnesota Journal of Law, Science \& Technology. 2006: 277-302.

8. Posthumous Reproduction: A review of the current Guidelines for the Storage, Use, and Disposal of Sperm from a Deceased Man to take into account gametes and embryos. Available from: https://www.health. govt.nz/publication/posthumous-reproduction-review-currentguidelines-storage-use-and-disposal-sperm-deceased-man-take [reviewed 2020.08.20].

9. Where's My Share? Inheritance Rights of Posthumous Children. Available from: https://www.americanbar.org/groups/litigation/committees/ jiop/articles/2019/inheritance-rights-posthumous-children/[reviewed 2020.08.20].

10. Avramova 0 , Zhydkova 0 , The fourth generation of human rights [Chetverte pokolinnia prav liudyny]. Pravo Ukrainy. 2010; 2:101107. (Ua).

11. Checherskyi $V$, The use of cryopreserved gametes and embryos as a guarantee of the realization of the human right to reproductive reproduction [Vykorystannia kriokonservovanykh hamet ta embrioniv yak harantiia realizatsii prava liudyny na reproduktyvne vidtvorennia]. Yurydychnyi naukovyi elektronnyi zhurnal. 2019; 4:34-37. (Ua).

12. Dyrektyvy komisii 2006/17/les 8.02.2006 pro implementatsiiu Dyrektyvy Yevropeiskoho Parlamentu i Rady 2004/23/leS u chastyni deiakykh tekhnichnykh vymoh do donatsii, zahotivli ta testuvannia liudskykh tkanyn ta klityn. Available from: https://www.kmu.gov. ua/storage/app/sites/1/55-GOEEl/direktiva-komisii-2006-17-es.pdf [reviewed 2020.08.20].

13. Svytnev K, Legal and ethical aspects of posthumous reproduction [Pravovi y etycheskye aspekty posmertnoi reproduktsy]. Pravovy voprosy v zdravookhranenyy. 2011; 6:30-43. Available from: https:// svitnev.ru/nauchnie/pvz_30_43.pdf. [reviewed 2020.08.20] (Ru).

14. Lapuente S, New Developments in Spanish Succession Law. Electronic Journal of Comparative Law. 2010; 14.2: 7, 8. Available from: http:// www.ejcl.org [reviewed 2020.08.20].

15. Simeinyi kodeks Ukrainy: Zakon Ukrainy 10.01.2002 № 2947-III. Available from: https://zakon.rada.gov.ua/laws/show/2947-14\#Text [reviewed 2020.08.20] (Ua). 
16. Zahalna deklaratsiia prav liudyny: pryiniata i proholoshena rezoliutsiieiu 217 A (III) Heneralnhoi Asamblei 00N 10.12.1948. Available from: https://zakon.rada.gov.ua/laws/show/995_015\#Text [reviewed 2020.08.20].

17. Shyshka 0 . R. The right of a non-existent participant in civil relations as a legal fiction. [Pravo neisnuiuchoho uchasnyka tsyvilnykh pravovidnosyn yak pravova fiktsiia]. Pravo ta upravlinnia. 2011;1:505 (UA); Anykyna H.V. K voprosu o pravovom rehulyrovanyy postmortalnoi reproduktsyy. Nauka. Obshchestvo. Hosudarstvo: elektron. nauchn. zhurnal. 2013; 2: 8. Available from: http://esj.pnzgu.ru/page/13437. [reviewed 2020.08.20] (Ua).

18. Hudyma $D, A$ dead person as a subject of law (non-trivial thoughts). [Pomerla liudyna yak subiekt prava (netryvialni dumky)]. Pravo Ukrainy. 2010;12:260.

19. Hrazhdanskoe ulozhenye Hermanyy: Vvodnii zakon k Hrazhdanskomu ulozhenyiu = Bürgerliches Gesetzbuch Deutschlands mit Einführungsgesetz; per. s nem. / V. Berhmann, vved., sost.; nauch. red. T. F. Yakovleva. 4-e yzd., pererab. Moskva:Ynfotropyk Medya, 2015. $888 \mathrm{p}$.

\section{ORCID and contributionship:}

Olga Ye Avramova: 0000-0002-1941-9894 ${ }^{\text {A,D,E }}$

Oleksandr Ye Kukhariev: 0000-0003-2086-9179 A,E,F

\section{Conflict of interest:}

The Authors declare no conflict of interest.

\section{CORRESPONDING AUTHOR}

\section{Oleksandr Ye. Kukhariev}

Kharkiv National University of Internal Affairs

61080, Kharkiv, Ukraine, 27, Lev Landau Avenue

tel: +380506053042

e-mail:kukharyev@gmail.com

Received: 25.08 .2020

Accepted: 30.11 .2020

A - Work concept and design, B - Data collection and analysis, C - Responsibility for statistical analysis,

D-Writing the article, $\mathbf{E}$-Critical review, $\mathbf{F}$ - Final approval of the article 